\title{
Baalsaurus mansillai gen. et sp. nov. a new titanosaurian sauropod (Late Cretaceous) from Neuquén, Patagonia, Argentina
}

\author{
JORGE O. CALVO ${ }^{1,2}$ and BERNARDO GONZALEZ RIGA ${ }^{3}$
}

\author{
${ }^{1}$ Parque Natural Geo-Paleontológico Proyecto Dino, Grupo de Transferencia Proyecto Dino, Ruta Prov. 51, Km 65, Facultad de \\ Ingeniería, Departamento de Geología y Petróleo, Universidad Nacional del Comahue, Bs. As. 1400, 8300, Neuquén, Argentina \\ ${ }^{2}$ Facultad de Ciencias Exactas y Naturales, Universidad Nacional de la Pampa, \\ Av. Uruguay 151, 6300, Santa Rosa, La Pampa, Argentina \\ ${ }^{3}$ Consejo Nacional de Investigaciones Cientificas y Tecnicas/CONICET, Laboratorio y Museo \\ de Dinosaurios, Facultad de Ciencias Exactas y Naturales, Universidad Nacional de Cuyo, Paseo \\ Padre Contreras 1300, Parque General San Martin, 5500, Mendoza, Argentina \\ Manuscript received on June 27, 2018; accepted for publication on August 20, 2018
}

\begin{abstract}
How to cite: CALVO JO AND RIGA BG . 2019. Baalsaurus mansillai gen. et sp. nov. a new titanosaurian sauropod (Late Cretaceous) from Neuquén, Patagonia, Argentina. An Acad Bras Cienc 91:e20180661. DOI 10.1590/00013765201820180661 .
\end{abstract}

\begin{abstract}
We describe a dentary of a new titanosaur sauropod, Baalsaurus mansillai, gen. et sp. nov. from the Late Cretaceous of Patagonia, Argentina. The material comes from the Portezuelo Formation, Neuquén Group. Titanosaur sauropods lower jaws are scarce and only nine taxa with dentaries have been described. There are two types of morphology in titanosaur dentaries; "L" shaped or "U" shaped based on the shape, without a phylogenetic issue. In this paper; we recognize a new taxa, Baalsaurus mansillai, represented by an "L" shaped dentary with three apomorphic characters that are not present in other taxa: dentary alveoli with 10 teeth in the anterior ramus, a ventrally and anteriorly inclined symphysis and a wide ventral Meckelian groove surrounded by a thin lamina that forms a keel on the ventral border of the dentary.
\end{abstract}

Key words: Argentina, Dinosauria, Neuquén, Sauropoda, Upper Cretaceous.

\section{INTRODUCTION}

Since more than 100 years ago, titanosaur sauropods have been some of the most common record of dinosaur fossils from Gondwanan continents. South America, and specifically, Argentina, have yielded numerous taxa (de Jesús Faria et al. 2015 and bibliography herein); however, cranial material has been scarce in most of the quarries

Correspondence to: Jorge Orlando Calvo

E-mail: jocalvomac@gmail.com

ORCid: http://orcid.org/0000-0003-4729-6585

* Contribution to the centenary of the Brazilian Academy of Sciences. discovered. Around the world, there are only a few titanosaur with some complete skulls, such those of Nemegtosaurus mongoliensis (Nowinsky 1971), Rapetosaurus krausei (Curry Rogers and Forster 2004), Sarmientosaurus musacchioi (Martinez et al. 2016), Malawisaurus dixeyi (Haughton 1928) and Tapuiasaurus macedoi (Zaher et al. 2011) and several complete embrionyc titanosaur skulls (Chiappe et al. 2001, Garcia et al. 2010). Moreover, there are other papers related to less complete cranial materials such as either partial cranium or basicranium in Saltasaurus loricatus (Bonaparte and Powell 1980), Quesitosaurus orientalis 
(Kurzanov and Banikov 1983), Muyelensaurus pecheni (Calvo et al. 2007a), a surangular, angular, prefrontal and teeth in Rinconsaurus caudamirus (Calvo and Riga 2003), teeth in Ampelosaurus atacis (Le Loeuff 1995, 2005), Alamosaurus sanjuanensis (Kues et al. 1980) a postorbital and teeth in Quetecsaurus rusconii (Gonzalez Riga and Ortiz 2014), some teeth in Alamosaurus sanjuanensis (Kues et al 1980), a basicranium and teeth in Mongolosaurus haplodon (Gilmore 1933, Mannion 2010), a Maxilla in Maxakalisaurus topai (Kellner et al. 2006) and in Dreadnoughtus schrani (Lacovara et al. 2014), in several unnamed basicraniums (Le Loeuff et al. 1989, Tidwell and Carpenter 2003, Calvo and Kellner 2006, García et al. 2008), and several maxilla (Calvo et al. 2014, Coria and Chiappe 2001, Sciutto and Martinez 1994).

Titanosaur complete lower jaw is recorded for Nemegtosaurus mongoliensis (Nowinski 1971). Isolated bones from the lower jaw have been described for some taxa such as in Antarctosaurus wichmanianus (Huene 1929), Ampelosaurus atacis (Le Loeuf 2005), Bonitasaura salgadoi (Apesteguia 2004, Gallina and Apesteguia 2011), Rapetosaurus krausei (Curry Rogers and Forster 2004) and Quaesitosaurus (Kurzanov and Banikov 1983), Karongasaurus gittelmani (Gomani 2005), Brasilotitan nemophagus (Machado et al. 2013) Choconsaurus bayleiwillisi (Simón et al. 2018). Recently, Garcia and Cerda (2010) published a detailed study about tooth replacement in a partial left titanosaur dentary based on alveoli $5^{\text {th }}$ or $7^{\text {th }}$ to $11^{\text {th }}$ or $13^{\text {th }}$. The combination of having strongly rectangular anterior dentary and chisellike teeth in this taxon confirms the hypothesis that, in titanosaur sauropods, a square symphysis was present (Apesteguia 2004). Therefore, the dentary described herein was mentioned briefly in Calvo et al. (2015), corresponds to a new titanosaur sauropod taxon based on a unique combination of characters.
Institutional abbreviations: $\mathrm{AMNH}$, American Museum of Natural History, New York, USA; MUCPv, University of Comahue Museum Paleovertebrates, Geo-Paleontólogical Natural Park Proyecto Dino, Barreales Lake, Neuquén, Argentina; MCSPv, Cinco Saltos Museum of Paleovertebrates, Cinco Saltos, Río Negro, Argentina.

\section{SYSTEMATIC PALEONTOLOGY}

SAURISCHIA Seeley, 1887

SAUROPODA Marsh, 1878

TITANOSAURIFORMES Salgado et al. 1997

TITANOSAURIA Bonaparte and Coria, 1993

Baalsaurus gen. nov.

ZooBank Life Science Identifier (LSID) urn:1sid:zoobank.org:act:72AE012A-018A-4B4B950F-3CCB4C1D2471

Type Species: Baalsaurus mansillai gen. et sp. nov.

Etymology: The generic name is dedicated to the dinosaur site named Baal. Baal means the fertility god, whose cult was widespread in ancient Phoenician and Canaanite lands and saurus, a reptile.

Diagnosis: As for the species.

Baalsaurus mansillai gen. et sp. nov.

Holotype: The specimen is represented by an almost complete right dentary with 13 alveoli housed at the Geology and Paleontology Museum of the National University of Comahue Museum, Parque Natural Geo-Paleontológico Proyecto Dino, Barreales Lake, Neuquén Argentina. MUCPv 1460; Figs. 3-7).

Etymology: The species, mansillai, honors to Mr. Juan Eduardo Mansilla, a technician at the Geology and Paleontology Museum of the National University of Comahue, Parque Natural 
Geo-Paleontológico Proyecto Dino, Barreales Lake, who discovered the material.

Type Locality and Age: North coast of Barreales lake at Baal site (Fig. 1). Portezuelo Formation (Fig. 2), Neuquén Group, Upper Cretaceous, Turonian-Coniacian (Leanza and Hugo 2001).

Diagnosis: Baalsaurus differs from other titanosaurs in the following combination of features: a) dentary alveoli with 10 alveoli on the anterior ramus, b) dentary with ventrally and anteriorly inclined symphysis and c) wide ventral meckelian groove surrounded by a thin lamina that form a keel in the ventral border of the dentary.

\section{DESCRIPTION}

The material described here is an almost complete right dentary of a titanosaur (Fig. 3-7). The tooth row begins just posterior to the symphysis and thirteen alveoli are present (Fig. 3). Replacement foramina are visible on the medial margin of the tooth row as are also present in Nemegtosaurus (Nowinski 1971) and Karongasaurus (Gomani 2005). There are at least three teeth replacement in each alveolous (Fig. 7). All of the preserved teeth are pencil-like as in other titanosaurs (Fig. 3, 7). The dentary in dorsal view is L-shaped forming a strong 90 degrees angle between anterior and posterior ramus giving a square jaw morphology (different to Nemegtosaurus and Rapetosaurus but similar to Antarctosaurus). The anterior margin is straight, where, ten alveoli are placed in the rostral or anterior ramus (Fig. 3). The alveolar segment of the dentary has a large anterior ramus and short posterior ones. Another alveolus, the biggest one, is placed at the corner of the "L" shape, and the other small three ones, are placed laterally. The articulated dentaries would have formed a rectangular shape as in some titanosaurs such as Antarctosaurus wichmanianus (Huene 1929), and diplodocids (McIntosh and Berman 1975). Just in

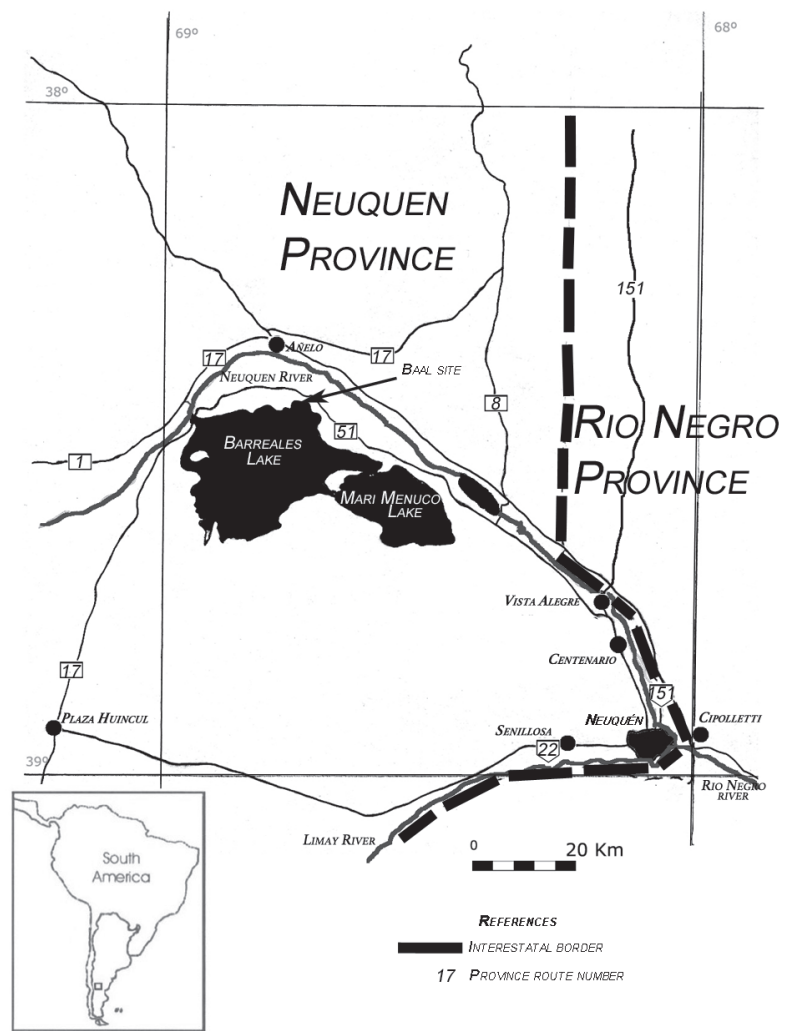

Figure 1 - Map of Neuquén Basin (Patagonia, Argentina) showing the locality where the holotype Baalsaurus mansillai gen. et sp. nov. was found.

the $10^{\text {th }}$ alveoli it is possible to recognize an unworn tooth in the bottom of it. The posterior ramus of the dentary, in the lateral view, has been slightly displaced inward by postmortem deformation (Fig. 5 ), but this distortion is not seen in medial view (Fig. 4). Therefore, the medial side shows the real shape of the dentary in dorsal view. No dorsal and ventral rami have been preserved on the posterior part of the dentary.

The symphysis shape is subtriangular, higher than wider, and it is directed ventrally and forward. The symphyseal region is complete but the distal dentary is not well preserved. The dentary symphysis is inclined ventrally and inclines forward, a character not seen in other titanosaurs (Fig. 6).

In anterior view (Fig. 3), the dentary is deep dorsoventrally; the dorsal margin of the 


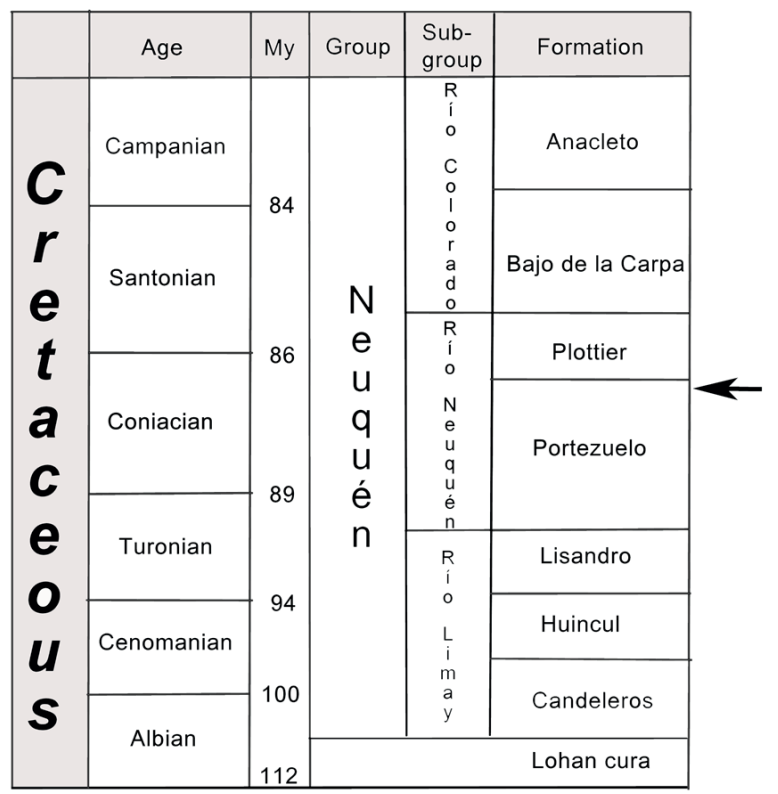

Figure 2 - Stratigraphic column of the Neuquén Group showing the age of Baalsaurus mansillai n.g.n.sp. (arrow). My, millions of years. (modified from Calvo et al. 2007b). M.y.: Millions of years.

alveolar series is almost straight; and the ventral border is strongly convex as in Antarctosaurus wichmanianus (Huene 1929). From the symphysis, the dentary deepens backward; this expansion is well developed from the $3^{\text {rd }}$ to the $8^{\text {th }}$ alveoli. From there, the ventral border runs almost in a straight line from the anterior side to the lateral end (Fig. 4-6). The ventral border of the dentary possesses on its anterior portion a very thin lamina or keel that born at the level from the $3^{\text {rd }}$ alveoli and disappear at the level of the $8^{\text {th }}$ alveoli (Fig. 5). On the medial side, the keel is slightly curved upward, probably to enclose the Meckelian groove (Fig. 4-6).

In lingual or medial view, the dental vascular foramina of the alveolar series are well exposed (Fig. 4). The $1^{\text {st }}$ dental foramen is placed $11 \mathrm{~mm}$ down of the alveolar margin, dental foramen $9^{\text {th }}$ is few $\mathrm{mm}$ below and the thirteen dental foramen is placed close to the alveolar margin (Fig. 3, 4, 6D). The dental foramina line is almost parallel to the ventral margin of the dentary, if we do not consider the ventral keel that encloses the Meckelian groove. The Meckelian groove is wide anteriorly and surrounded by a keel that turns lingually (Fig. $4,6 \mathrm{D})$. The depth of the Meckelian canal decreases posteriorly from alveolous $2^{\text {nd }}$ to $8^{\text {th }}$; and then from that point, it runs below the ventral border of the dentary on an almost flat surface and. Near the symphysis, the groove rises slightly to form a prominent notch on the ventral side of the articular surface (Fig. 4).

In dorsal view (Fig. 3), the curvature of the dentary, towards the midline, begins at the level of its minimum vertical depth, the $10^{\text {th }}$ alveoli (as in Rapetosaurus). The outlines of the alveoli are subcirculars from the $1^{\text {st }}$ to $7^{\text {th }}$, the $8^{\text {th }}$ is circular, the $9^{\text {th }}$ and $10^{\text {th }}$ are almost fused, with the $10^{\text {th }}$ the largest in the series. The $11^{\text {th }}$ to $13^{\text {th }}$ alveoli are on the lateral side of the dentary and are somewhat crushed, and very small.

A CT-Scan shows that there are at least three teeth in each alveolous, one belongs to one worn and two unworn teeth inside the dentary (Fig. 7). This is also present in a detailed study made on the Bonitasaura skull (Gallina and Apesteguia 2011), Antarctosaurus and in the fragmentary dentary of the titanosaur MCSPv-061 (García and Cerda 2010).

\section{COMPARISONS}

Dentaries with pencil-shaped teeth where used to include titanosaur + diplodocids (Coombs 1975, Dodson 1990, McIntosh 1990). However, Calvo (1994b) recognized differences in both lower jaw and tooth shape between titanosaurs and diplodocids: titanosaurs have chisel-like teeth with wear surface, among other characters, inclined 70 degrees or more with respect to the labio-lingual tooth axis. Diplodocids have peg-like teeth, with wear surface, inclined from 10 to 40 degrees with respect to the labio-lingual tooth axis. In sum, titanosaur's teeth can easily be distinguished from 


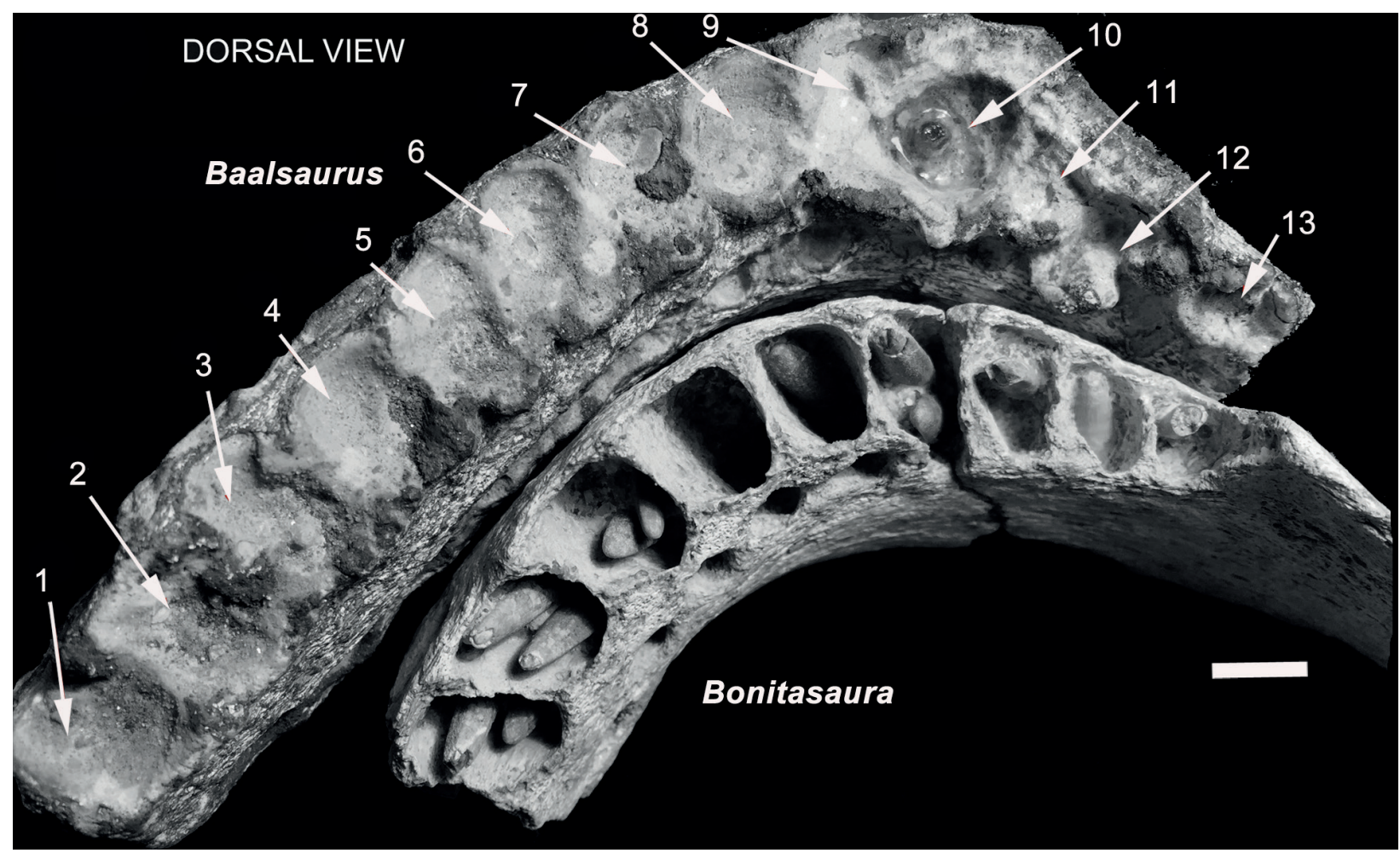

Figure 3 - showing alveoli in dorsal view of Baalsaurus mansillai n.g.n.sp. compared with Bonitasaura salgadoi. Scale bar: $1 \mathrm{~cm}$.

diplodocid ones and therefore, it is possible to recognize dentaries from one to another clades.

Different forms of titanosaur dentaries can be identified in dorsal view. Usually, there are two types of morphology in titanosaur dentaries; "L" shaped or "U" shaped; however, we can recognize three different morphologies based on the new discovery; "L" shaped, "U" Shaped and "smoothly curved" shaped.

One of them is characterized by having a "U shape" with teeth placed both on the anterior and lateral ramus on the dentary, such as those present in the titanosaurian taxa Rapetosaurus, Nemegtosaurus, Ampelosaurus, Karongasaurus, Quaesitosaurus and Tapuiasaurus and they are associated with an elongated rostrum with cylindrical teeth exposed laterally and a tooth row that extends up to the level of the preantorbital fenestra (Wilson 2005).
The second form has a rectangular shape or "L" shaped with teeth restricted mostly to the anterior ramus of the dentary as seen in the diplodocid Diplodocus (McIntosh and Berman 1975: fig. 5C), the rebacchisaurid Nigersaurus taqueti (Sereno et al. 1999) and the titanosaurs Antarctosaurus, Brasilotitan and the new taxon here described. Sauropod pencil like teeth are restricted to diplodocids and titanosaurs; however, jaw movement, tooth morphology and wear surface is different (Calvo 1994a, b). Because diplodocids belong to another clade of sauropods we are going to restrict our study only to titanosaur specimens.

The third form has a "smoothly curved" dentary and is present in Bonitasaura. Gallina and Apesteguia (2011) recognize this form as that present in Antarctosaurus but here we separate it because Bonitasaura dentary is more curved than Antarctosaurus and it is probably an intermedial 


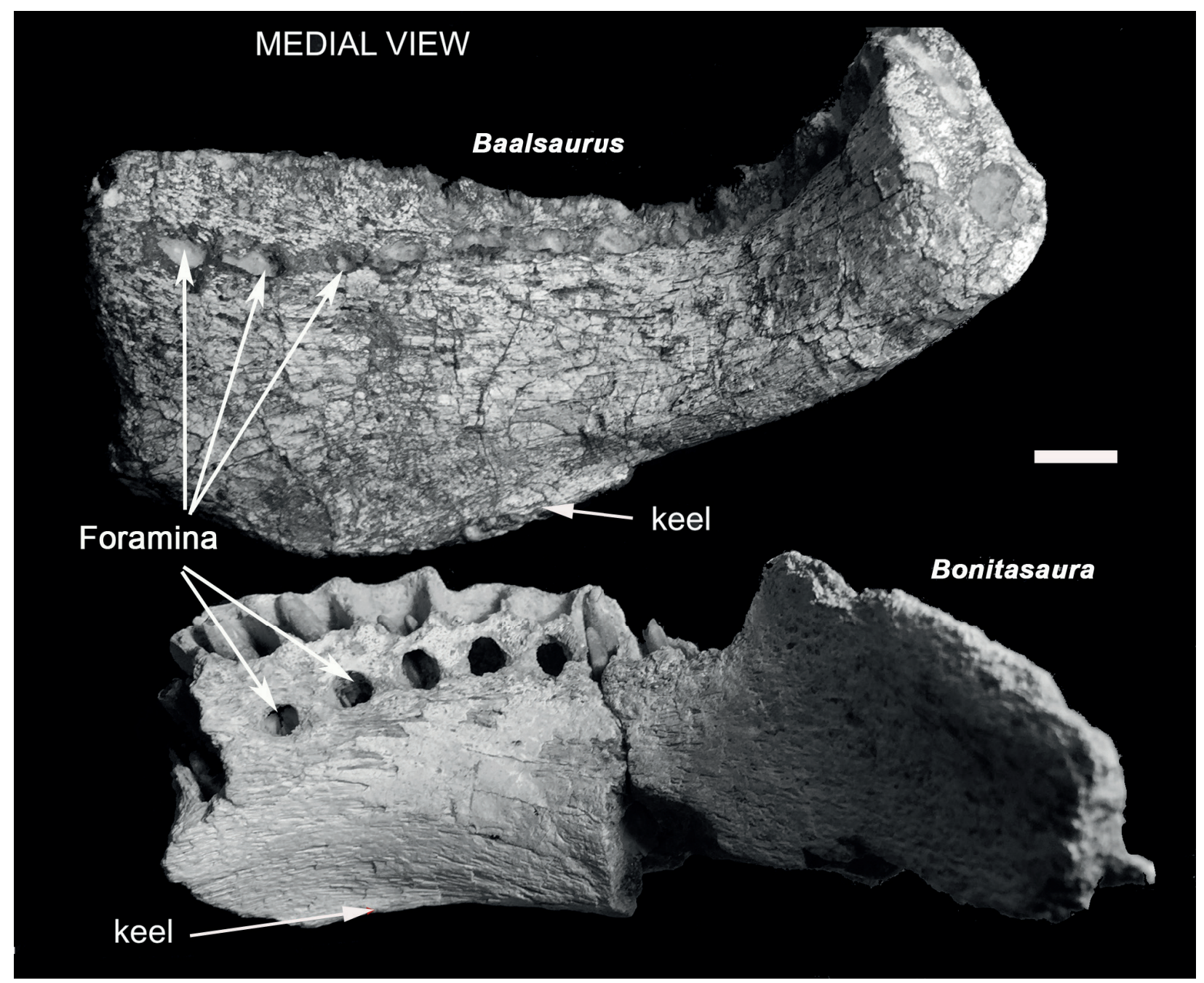

Figure 4 - Baalsaurus mansillai n.g.n.sp. medial view compared with Bonitasaura salgadoi. Scale bar: $1 \mathrm{~cm}$.

morphology between the curved Nemegtosaurus and the squared outline of Antarctosaurus.

The number of teeth is difficult to know in many taxa because of missing parts. It was demonstrated that in titanosaur sauropod; at least, this character is useful for taxonomy because it does not change during ontogeny (García et al. 2010). The teeth numbers in different titanosaur taxa is variable (Table I).

The dentary symphysis is transversely narrow and has a roughened sutural surface as in other sauropods (e.g. Camarasaurus, Madsen et al. 1995); but this is not present in other titanosaurs. The long axis of the dentary symphysis in
Baalsaurus inclines anteroventrally differently to Antarctosaurus wichmanianus, Sarmientosaurus, Quaesitosaurus, Karongasaurus, Nemegtosaurus and Tapuiasaurus where it is perpendicular to the long axis of the lower jaw, while in Malawisaurus, Bonitasaura and Diplodocus (McIntosh and Berman 1975) it inclines posteroventrally. In Brasilotitan; instead, the dorsal symphyseal region of the dentary twisted medially Therefore, the ventrally forward inclination of the symphysis is considered here an autopomorphy of Baalsaurus.

The Meckelian groove opens in the ventral symphysis differently to Nemegtosaurus that opens on the ventral third of the articular surface (Wilson 

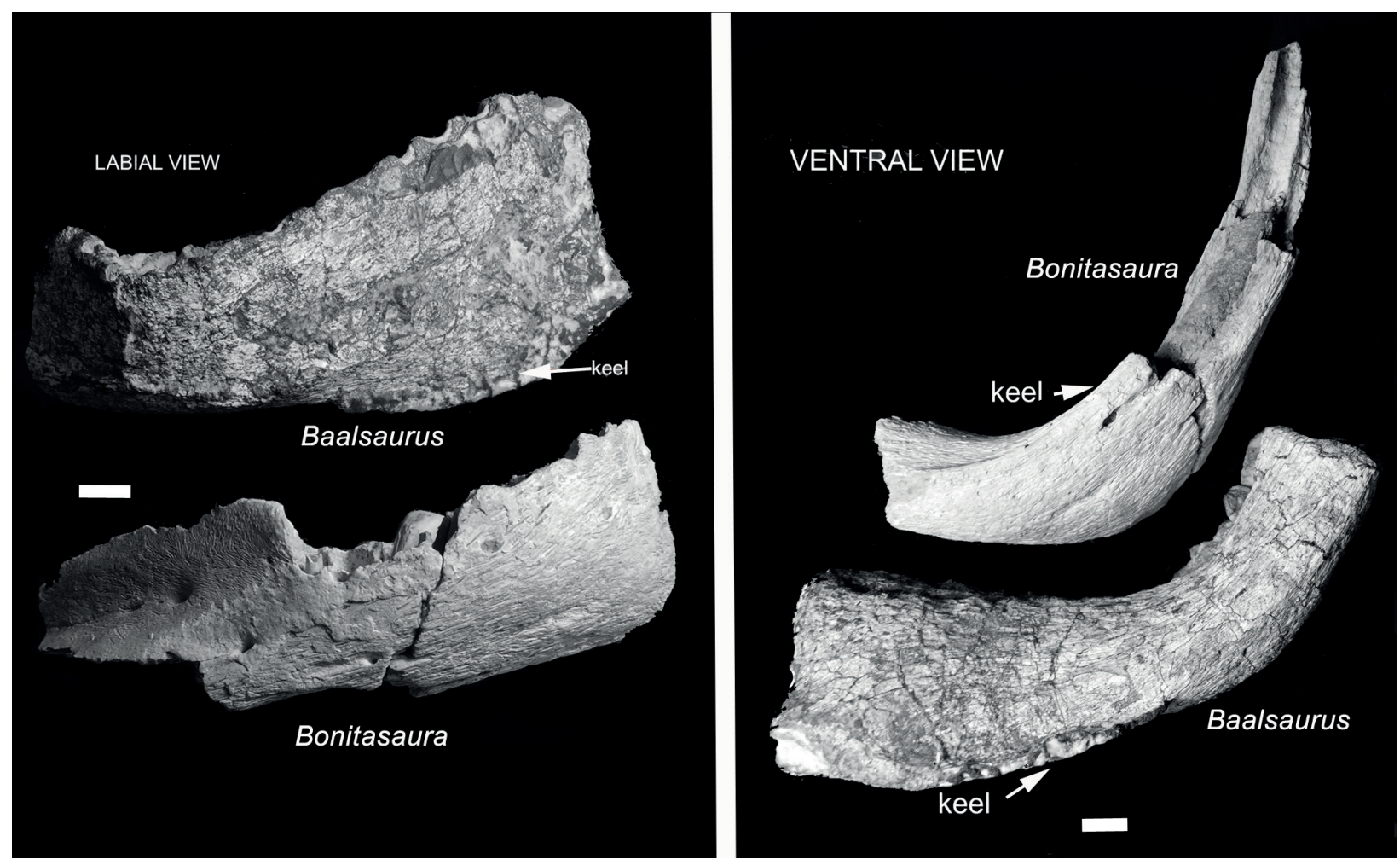

Figure 5 - Baalsaurus mansillai n.g.n.sp. labial and ventral view compared with Bonita aura salgadoi. Scale bar: $1 \mathrm{~cm}$.

TABLE I

Number of teeth present in dentaries of taxa described.

\begin{tabular}{lcc} 
Taxa & teeth & References \\
\hline Antarctosaurus wichmanianus & 18 & Huene 1929 \\
Malawisaurus dixeyi & 15 & Jacobs et al. 1993 \\
Brasilotitan nemophagus & 14 & $\begin{array}{c}\text { Machado et al. } \\
2013\end{array}$ \\
Nemegtosaurus mongoliensis & 13 & Nowinsky 1971 \\
Bonitasaura salgadoi & 13 & Apesteguia 2004 \\
Baalsaurus mansillai & 13 & This paper \\
Sarmientosaurus musacchioi & 13 & Martinez et al. \\
Karongasaurus gittelmani & 12 & Gomani 2005 \\
Choconsaurus bayleiwillisi & 11 & Simon el al. 2018 \\
Rapetosaurus krausei & 11 & Roger and Forster \\
Diplodocus longus & & Holland 1906, \\
Ampelosaurus atacis & 10 & Hatcher 1901 \\
\hline & 9 & Le Loeuf 2005 \\
\hline
\end{tabular}

2005) and to Tapuiasaurus that it does not reach the symphyseal region. The wide ventral Meckelian groove, surrounded by a thin lamina, forms a keel in the ventral border of the dentary, this character is considered an autopomorphy of Baalsaurus.

Baalsaurus shares with Antarctosaurus wichmanianus, Brasilotitan and Bonitasaurus salgadoi "L" shaped dentary (Fig.3). However, there are some differences that allow us to recognize it as a new taxon.

Comparing with Antarctosaurus wichmanianus the symphyseal anterior ramus is vertical but it not cants forward as in Baalsaurus. The posterior ramus and corner of the dentary of $A$. wichmanianus cants linguoventrally and in Baalsaurus is vertical. Unfortunately, there is not precision on the $A$. wichmanianus teeth number; but Huene (1929) count six on the posterior ramus and in the taxa here described there are just four. There is not a ventral 


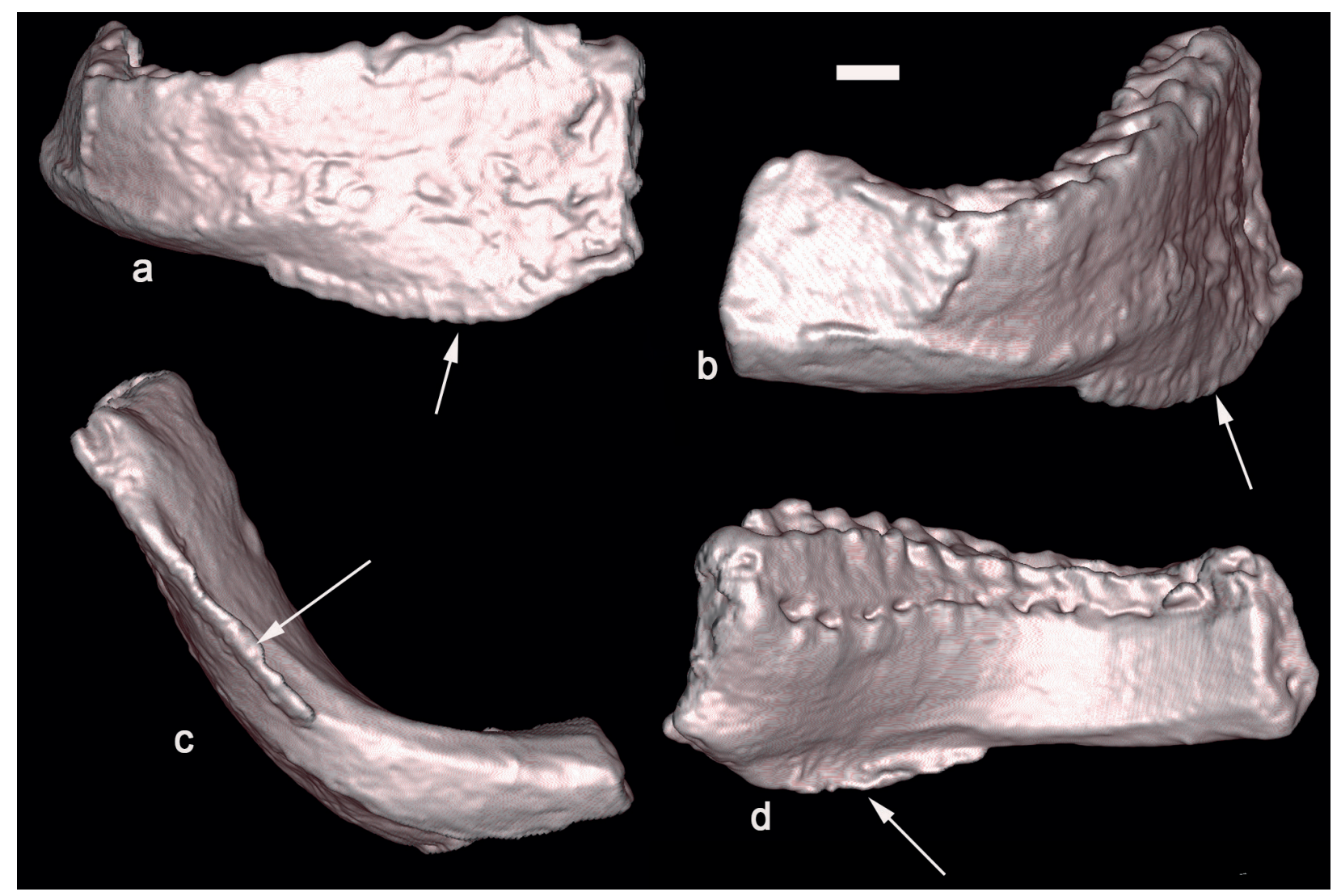

Figure 6 - Baalsaurus mansillai n.g.n.sp. a: anterior view, b: lateral view, c: ventral view and d: lingual view. Arrows point the keel.

keel in A. wichmanianus. The number of total teeth is eighteen different to Baalsaurus with thirteen.

Brasilotitan nemophagus has the dorsal symphyseal region of the dentary twisted medially and seven alveolous on the anterior ramus. However, in Baalsaurus, the symphysis is inclined antero-ventrally and it has ten alveolous on the anterior ramus.

The preserved mandible of Bonitasaura with "smoothly curved" shaped has 10 alveolus, some of them with teeth (Fig. 3), it should be one more and probably two disappeared (Apesteguia 2004, Gallina and Apesteguia 2011); therefore, it should have the same teeth number that Baalsaurus.

Compared with Bonitasaura dentary (Fig. 3-5); Baalsaurus has more differences; for instance, Bonitasaura has the curvature of the dentary less pronounced, and involve from alveoli
1 to $6^{\text {th }}$ then it goes straight producing a rectangular anterior ramus (Fig. 3). In Baalsaurus the curvature involves just the $10^{\text {th }}$ alveoli. Apesteguía (2004) diagnosed that "Bonitasaura differs from other titanosaurs in the following combination of features: dentary alveoli reduced in number (three in the main ramus, one in the angle, and up to seven in the anterior region)'. However, we recognize in Bonitasaura the presence of three alveoli in the main ramus, three in the angle (curvature) and up to four on the anterior ramus (Fig. 3). Alveolus shape in Bonitasaura is subcuadrangular with the labial side straight different to Baalsaurus where they are mainly subcircular with the labial side circular (Fig. 4). The dental foramina are big and placed close to the alveolar margin in Bonitasaura but in Baalsaurus they are small, and they are separated from the alveolar margin (Fig. 4). The 

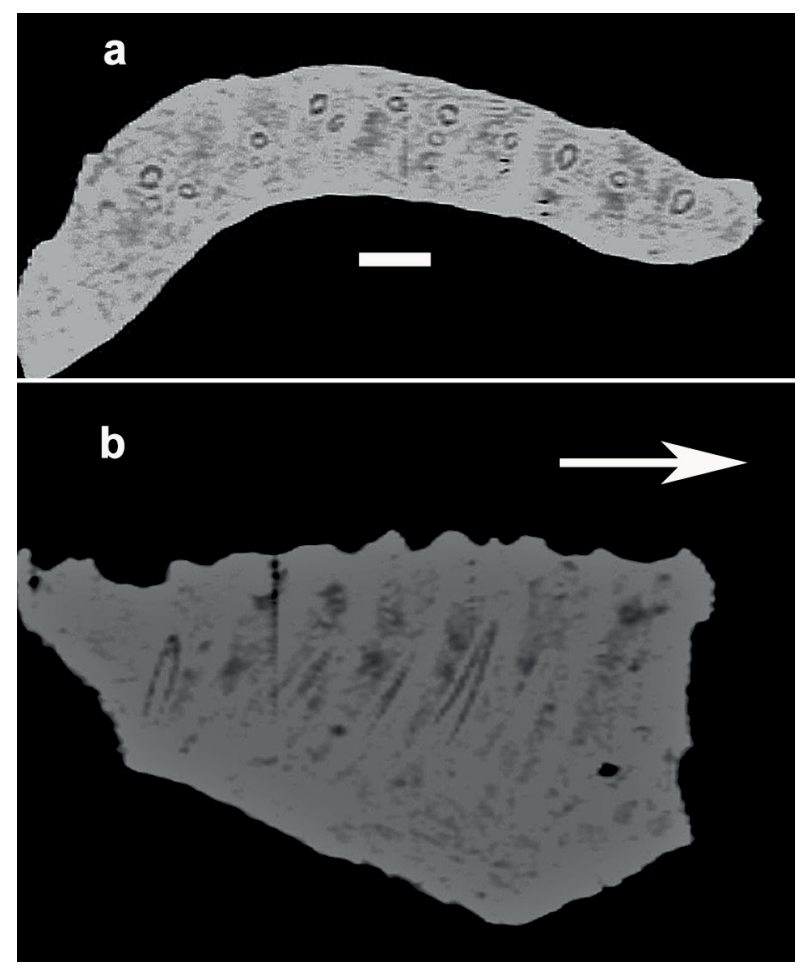

Figure 7 - Baalsaurus mansillai n.g.n.sp. Computed tomography-based digital visualization, a: slice in dorsal view, b: slice in lateral view. Arrows point to anterior. Scale bar: 1 $\mathrm{cm}$.

long axis of the dentary inclines strongly ventrally in Bonitasaura in such a way that the small kill present on the ventral side is placed horizontal as in Diplodocus; whereas in Baalsaurus it goes ventrally and then direct slightly forward (Fig. 5). Both labial and lingual side of the dentary is convex at the level of the $10^{\text {th }}$ alveolus in Bonitasaura but in Baalsaurus, at the level of the $10^{\text {th }}$ alveolus, the labial side is straight and then turnward labially being concave on the labial side and convex on the lingual one. In the ventral anterior side, near the symphysis there is a small keel in Bonitasaura but it is much stronger in Baalsaurus and very thin. No meckelian groove is seen in Bonitasaura but it is well developed in Baalsaurus (Fig.4).

Apesteguia (2010) stated that the character "middle and posterior region of the dentary edentulous and forming a sharp dorsal edge" is an autopomorphy of Bonitasaura. However, it has been recently described in Brasilotitan (Machado et al. 2013). This character is not preserved in Baalsaurus; but for the shape of the preserved portion, it could have been present.

Finally, García and Cerda (2010) describe in detail a fragment of a titanosaur dentary from Anacleto Formation with seven alveoli, here considered $7^{\text {th }}$ to $13^{\text {th }}$ as it was supposed by García and Cerda (2010). The material classified as CSPv061 shows a morphology similar to Baalsaurus in having a rectangular shape with convex lingual side dentary and a slightly straight labial side. The dental foramina are well separated from the alveolar margin as in Baalsaurus. The section of this material is relatively thin has in Baalsaurus. Alveoli in CSPv-061 are rounded similar to Barreales material. The symphysis is not well preserved but the section is subtriangular as in Baalsaurus.

According to the evidence the "L" shaped morphology of Antarctosaurus, Brasilotitan, Baalsaurus and the CSPv-061 dentary could be close relative.

\section{CONCLUSIONS}

In spite that "L" shape dentaries with teeth restricted to the anterior ramus of the dentary is shared between some titanosaur and diplodocid taxa, there are some morphological differences between them such as teeth placement and worn surface (Calvo 1994a, b). Baalsaurus mansillai is a titanosaur of medium size, with an estimated skull length of $40 \mathrm{~cm}$ compared con that obtained from Bonitasaura (Gallina and Apesteguia 2011). Dentary is similar to that of Antarctosaurus wichmanianus and Bonitasaura salgadoi because they share rectangular anterior snout, vertical teeth and restricted mostly to the anterior part of the dentary. Baalsaurus mansillai differs from Antarctosaurus wichmanianus and Bonitasaura salgadoi in having a vertical corner between anterior and posterior ramus. Baalsaurus mansillai is characterized by having a dentary with ventrally and forward inclination of the symphysis and a 
wide ventral meckelian groove surrounded by a thin lamina that form a keel in the ventral border of the dentary.

\section{ACKNOWLEDGMENTS}

Our special thanks to Juan Eduardo Mansilla, technician from the Geo-Paleontological Natural Park Proyecto Dino for his important discoveries on the field that have improved the knowledge of the record of fauna in the area. We have to thank to Dr. Paul Barret and an anonymous reviewer that improved substantially this paper. This project was supported by the National University of Comahue 04-I-231/2017; Oil company Chevron S.A. and Fundación Luciérnaga (Proyecto Dino to JOC).

\section{REFERENCES}

APESTEGUÍA S. 2004. Bonitasaura salgadoi gen. et sp. nov.: a beaked sauropod from the Late Cretaceous of Patagonia. Naturwissenschaften 91: 493-497.

BONAPARTE JF AND CORIA RA. 1993. Un nuevo y gigantesco saurópodo titanosaurio de la Formación Río Limay (Albiano-Cenomaniano) de la provincia del Neuquén, Argentina. Ameghiniana 30: 271-282.

BONAPARTE JF AND POWELL JE. 1980. A continental assemblage of tetrapods from the Upper Cretaceous beds of El Brete, Northwestern Argentina (SauropodaCoelurosauria Carnosauria-Aves). Mèm Soc Gèol Fr NS 139: 19-28.

CALVO JO. 1994a. Feeding mechanism in some sauropod dinosaurs. Master Thesis. University of Illinois at Chicago, 142 p. (Unpublished).

CALVO JO. 1994b. Jaw mechanics in sauropod dinosaurs Gaia 10: 183-193.

CALVO JO, GONZÁLEZ RIGA BJ AND MANSILLA JE. 2015. Nuevos hallazgos de vertebrados en la Formación Portezuelo, Cetacico superior, Neuquén, Argentina. IX Jornadas Ciencias de la Tierra, p. 10.

CALVO JO, GONZÁLEZ-RIGA BJ AND PORFIRI JD. 2007a. A new titanosaur sauropod from the Late Cretaceous of Neuquén, Patagonia, Argentina. Arquivos do Museu Nacional, Rio de Janeiro 65: 485-504.

CALVO JO AND KELLNER AA. 2006. Description of a sauropod dinosaur braincase (Titanosaurae) from the Late Cretaceous Rio Colorado Subgroup, Patagonia. An Acad Bras Cienc 78: 175-182.

CALVO JO, PORFIRI JD, GONZALEZ RIGA BJ AND KELLNER AW. 2007b. A new Cretaceous terrestrial ecosystem from Gondwana with the description of a new sauropod dinosaur. An Acad Bras Cienc 79: 529-541.
CALVO JO, PORFIRI JD, PANTOJA G AND ORELLANA M. 2014. Nuevos aportes morfológicos a las mandíbulas de los saurópodos titanosaurae. XIX Congreso Geológico Argentino.

CALVO JO AND RIGA BJG. 2003. Rinconsaurus caudamirus gen. et sp. nov., a new titanosaur (Dinosauria, Sauropoda) from the Late Cretaceous of Patagonia, Argentina. Revista Geológica de Chile 30: 333-353.

CHIAPPE LM, SALGADO L AND CORIA RA. 2001. Embryonic Skulls of Titanosaur Sauropod Dinosaurs. Science 293: 2444-2446.

COOMBS WP JR. 1975. Sauropod habits and habitats. Palaeogeography, Palaeoclimatology, Palaeoecology 17: $1-33$.

CORIA RAAND CHIAPPE LM. 2001. Tooth replacement in a sauropod maxilla from the Upper Cretaceous of Patagonia, Argentina. Ameghiniana 38: 463-466.

CURRY ROGERS KA AND FORSTER CA. 2004. The skull of Rapetosaurus krausei (Sauropoda: Titanosauria) from the Late Cretaceous of Madagascar. J Vert Paleontol 24: 121-144.

DE JESUS FARIA CC, GONZÁLEZ RIGA B, DOS ANJOS CANDEIRO CR, DA SILVA MARINHO T, ORTIZ DL, SIMBRAS FM, CASTANHO RB, MUNIZ FP AND GOMES DA COSTA PEREIRA PVL. 2015. Cretaceous sauropod diversity and taxonomic succession in South America. J S Am Earth Sci 61: 154-163.

DODSON P. 1990. Sauropod Paleoecology. In: Weishampel DB, Dodson P and Osmolska H (Eds), The Dinosauria. $1^{\text {st }}$ ed., Berkeley: University of California Press, p. 402-407.

GALLINA PA AND APESTEGUÍA S. 2011. Cranial anatomy and phylogenetic position of the titanosaurian sauropod Bonitasaura salgadoi. Acta Palaeontologica. Polonica 56: 45-60.

GARCIA RA AND CERDA IA. 2010. Dentición de titanosaurios (Dinosauria, sauropoda) del Cretácico Superior de la provincia de Río Negro, Argentina: morfología, inserción y reemplazo. Ameghiniana 47: 45-60.

GARCÍA RA, PAULINA-CARABAJAL A AND SALGADO L. 2008. Un nuevo basicráneo de titanosaurio de la Formación Allen (Campaniano-Maastrichtiano), Provincia de Río Negro, Patagonia, Argentina. Geobios 41: 625-633.

GARCIA RA, SALGADO L, CORIA RAAND CHIAPPE LM. 2010. Osteología embrionaria de saurópodos titanosaurios de Neuquén (Argentina): aspectos ontogenéticos y evolutivos. Ameghiniana 47(4): 409-430.

GILMORE CW. 1933. Two new dinosaurian reptiles from Mongolia with notes on some fragmentary specimens. Am Mus Novit 679: 1-20.

GOMANI EM. 2005. Sauropod dinosaurs from the Early Cretaceous of Malawi, Africa. Palaeontol Electron 8: 1-37.

GONZÁLEZ RIGA B AND ORTÍZ DL. 2014. A new titanosaur (Dinosauria, Sauropoda) from the Upper Cretaceous (Cerro Lisandro Formation) of Mendoza Province, Argentina. Ameghiniana 51: 3-25. 
HATCHER JB. 1901. Diplodocus (Marsh): Its osteology, taxonomy, and probable habits, with a restoration of the skeleton. Mem Carnegie Mus 1: 1-63.

HAUGHTON SH. 1928. On some remains from the Dinosaur Beds of Nyasaland. Trans R Soc S Afr 16: 67-75.

HOLLAND WJ. 1906. Osteology of Diplodocus Marsh. Mem Carnegie Mus 2: 225-278.

VON HUENE F. 1929. Los Saurísquios y Ornitísquios del Cretácico Argentino. Anales Museo de La Plata, $2^{\text {nd }}$ serie 3: 1-196.

JACOBS LL, WINKLER DA, DOWNS WR AND GOMANI EM. 1993. New material of an Early Cretaceous titanosaur sauropod dinosaur from Malawi. Palaeontology 36: 523-534.

KELLNER AWA, AZEVEDO SAK, TROTTA MNF, HENRIQUES DDR, CRAIK MMT AND SILVA HP. 2006. On a new titanosaur sauropod from the Bauru Group, Late Cretaceous of Brazil. Boletín do Museu Nacional (Nova Serie) 2007: 1-31.

KUES BS, LEHMAN T AND RIGBY JK JR. 1980. The teeth of Alamosaurus sanjuanensis, a late Cretaceous sauropod. J Paleontol 54(4): 864-869.

KURZANOV SM AND BANIKOV AF. 1983. A new sauropod from the Upper Cretaceous of Mongolia. Paleontol Zhurnal 2: $90-96$

LACOVARA KJ ET AL. 2014. A Gigantic, Exceptionally Complete Titanosaurian Sauropod Dinosaur from Southern Patagonia, Argentina. Sci Rep 4: 6196.

LEANZA HA AND HUGO CA. 2001. Cretaceous red beds from southern Neuquén Basin (Argentina): age, distribution and stratigraphic discontinuities. In: Leanza HA (Ed), VII International Symposium on Mesozoic Terrestrial Ecosystems. Buenos Aires. Asociación Paleontológica Argentina 7: 117-122.

LE LOEUFF J. 1995. Ampelosaurus atacis (nov. gen., nov. sp.), un nouveau Titanosaurae (Dinosauria, Sauropoda) du Crétacé supérieur de la Haute Vallée de l'Aude (France). Comptes Rendus Acad Sci Paris 321 (ser. IIa): 693-699.

LE LOEUFF J. 2005. Osteology of Ampelosaurus atacis (Titanosauria) from southern France. In: Tidwell $\mathrm{V}$ and Carpenter K (Eds), Thunder-Lizards: The Sauropodomorph Dinosaurs. Bloomington: Indiana University Press, p. 115137.

LE LOEUFF J, BUFFETAUT E, MECHIN P AND MECHINSALESSY A. 1989. Un arrière-crâne de dinosare titanosauré dinosaur braincase (Saurischia, Sauropoda) dans le Crétacé supériur du Var (Provence, France). Comptes Rendus Acad Sci Paris 309 (II): 851-857.

LYDDEKER R. 1893. Contributions to the study of the fossil vertebrates of Argentina. I, the dinosaurs of Patagonia. Anales del Museo de La Plata, Paleontología 2: 1-14.

MACHADO EB, AVILLA LS, NAVA WR, CAMPOS DAAND KELLNER AWA. 2013. A new titanosaur sauropod from the Late Cretaceous of Brazil. Zootaxa 3701:301-321.
MADSEN J JR, MCINTOSH JS. AND BERMAN DS. 1995. Skull and atlas - axis complex of the Upper Jurassic sauropod Camarasaurus Cope (Reptilia: Saurischia). Bull Carnegie Mus Nat Hist 31: 1-115.

MANNION PD. 2010. A reassessment of Mongolosaurus haplodon Gilmore, 1933, a titanosaurian sauropod dinosaur from the Early Cretaceous of Inner Mongolia, People's Republic of China'. J Syst Palaeontol 9(3): 355-378.

MARSH OC. 1878. Principal characters of American Jurassic dinosaurs. Part I. Am J Sci (Series 3) 16: 411-416.

MARTÍNEZ RDF, LAMANNA MC, NOVAS FE, RIDGELY RC, CASAL GA, MARTÍNEZ JE, VITAJRAND WITMER LM. 2016. A Basal Lithostrotian Titanosaur (Dinosauria: Sauropoda) with a Complete Skull: Implications for the Evolution and Paleobiology of Titanosauria. https://doi. org/10.1371/ journal.pone.0151661.

MCINTOSH JS. 1990. Sauropoda. In: Weishampel DB, Dodson P and Osmólska H (Eds), The Dinosauria. Berkeley: University of California Press, p. 345-401.

MCINTOSH JS AND BERMAN DS. 1975. Description of the palate and lower jaw of the sauropod dinosaur Diplodocus (Reptilia: Saurischia) with remarks on the nature of the skull of Apatosaurus. J Paleontol 49: 187-199.

NOWINSKI A. 1971. Nemegtosaurus mongoliensis n. gen., n. sp. (Sauropoda) from the Uppermost Cretaceous of Mongolia. Palaeontologia Polonica 25: 57-81.

SALGADO L, CORIA RAAND CALVO JO. 1997. Evolution of titanosaur sauropods. I: Phylogenetic analysis based on the postcranial evidence Ameghiniana 34: 3-32.

SCIUTTO JC AND MARTINEZ RD. 1994. Un nuevo yacimiento fosilífero de la formación Bajo Barreal (Cretácico Tardío) y su fauna de saurópodos. Naturalia patagónica, Ciencias de la Tierra 2: 27-47.

SEELEY HG. 1887. On the classification of the fossil animals commonly called Dinosauria. Proc R Soc Lond 43: 221-228.

SERENO PC ET AL. 1999. Cretaceous sauropods from the Sahara and the uneven rate of skeletal evolution among dinosaurs. Science 286: 1342-1347.

SIMON E, SALGADO L AND CALVO JO. 2018. A new titanosaur sauropod from the upper Cretaceous of Patagonia, Neuquén province, Argentina. Ameghiniana 55: 1-29.

TIDWELL V AND CARPENTER K. 2003. Braincase of an early cretaceous titanosauriform sauropod from Texas. J Vert Paleontol 23(1): 176-180.

WILSON JA. 2005. Redescription of the Mongolian sauropod Nemegtosaurus mongoliensis Nowinski (Dinosauria: Saurischia) and comments on Late Cretaceous sauropod diversity. J Syst Palaeontol 3: 283-318.

ZAHER H, POL D, CARVALHO AB, NASCIMENTO PM AND RICCOMINI C. 2011. A Complete Skull of an Early Cretaceous Sauropod and the Evolution of Advanced Titanosaurians. PLoS ONE 6(2): e16663. 